F. Reprod. Fert. (1973) 33, 523-526

\title{
RESERPINE, ADRENALECTOMY AND THE REVERSAL OF THE EARLY ACTION OF CADMIUM ON SCROTAL AND CRYPTORCHID TESTES IN THE RAT
}

\author{
PARTHASANKAR RAY AND AMAR GHATTERJEE \\ Department of Physiology, Raja Peary Mohan College, Uttarpara, Hooghly, \\ West Bengal, India
}

(Received 16th November 1972)

The deleterious effect of cadmium on the testis has been ascribed to failure of regulation of the testicular temperature by the pampiniform plexus (Turner, 1966) and cadmium-induced damage to the capillary endothelium (Maekawa, Tsunenari \& Kurematsu, 1966; Gunn, Gould \& Anderson, 1963). Our recent findings in the rat of an early differential effect of cadmium on the scrotal and contralateral cryptorchid testes in the same individual do not entirely support the theory implicating the pampiniform plexus as the site of cadmium action (Chatterjee \& Ray, 1972). The higher rate of incorporation of tritiated lysine in a cryptorchid testis compared to its scrotal counterpart (Davis, 1965) suggests that the abdominal temperature may cause an initial heat-induced vasodilatation of the spermatic vasculature and thereby augment the blood flow through the cryptorchid testis (Glover, 1965). This paper describes our findings concerning the effect of reserpine or adrenalectomy in preventing an early detrimental and differential influence of cadmium on intact and surgically manipulated cryptorchid testes.

Laboratory-bred rats weighing 150 to $160 \mathrm{~g}$ were used. The animals were made unilaterally cryptorchid (ULC) by surgical manipulation. All rats, except the untreated controls, received a course of daily subcutaneous injections of reserpine (Serpasil ${ }^{*}$ ). The first two injections of reserpine $(2 \mathrm{mg} / \mathrm{kg}$ ) were given at 36 and $12 \mathrm{hr}$ before the injection of cadmium chloride $(0.45$ $\mathrm{mg} / 100 \mathrm{~g}$ in $0.2 \mathrm{ml} 0.9 \% \mathrm{NaCl}$ ). Cadmium was administered subcutaneously $2 \mathrm{hr}$ after the operation. The third, fourth and fifth doses of reserpine were reduced to $1 \mathrm{mg} / \mathrm{kg}$ and injected 12,36 and $60 \mathrm{hr}$ after the cadmium administration. The reserpine and cadmium control rats received either reserpine or cadmium alone. Rats were killed $72 \mathrm{hr}$ after the cadmium injection.

The testes, accessory sex organs and adrenal glands from each rat were removed, trimmed of adhering tissue and weighed. One testis was kept for histological examination in order to compare the degree of morphological changes in the different groups of rats with changes in weight.

The experimental data obtained are summarized in Table 1. The untreated and reserpine-treated ULG rats did not show any significant differences between the cryptorchid and intact scrotal testes or in the accessory sex organs 
in terms of weight and histology. The testes and accessory sex organs of the reserpine-treated controls, however, appeared pale compared to those of the untreated controls. The deleterious effect of cadmium in the control rats was greater in the intra-abdominal than in the contralateral scrotal testes in terms of changes in weight $(830.0 \pm 53.8$ versus $1142.0 \pm 56.2 \mathrm{mg})$ and coloration, due to possible alterations of vascular supply as well as histology. The adrenal glands of the cadmium-treated rats showed a significant gain in weight compared to those of the untreated controls.

Table 1. Effect of reserpine or adrenalectomy on the differential detrimental effect of cadmium chloride on intrascrotal and contralateral cryptorchid testes in the rat

\begin{tabular}{|c|c|c|c|c|c|c|c|}
\hline \multirow{2}{*}{ Treatment } & \multirow{2}{*}{$\begin{array}{l}\text { No. } \\
\text { of } \\
\text { rats }\end{array}$} & \multicolumn{2}{|c|}{ Testes } & \multirow{2}{*}{$\begin{array}{l}\text { Seminal } \\
\text { vesicle }\end{array}$} & \multirow{2}{*}{ Prostate } & \multirow{2}{*}{$\begin{array}{l}\text { Epididy- } \\
\text { mis }\end{array}$} & \multirow{2}{*}{ Adrenal } \\
\hline & & $\begin{array}{l}\text { Corpt- } \\
\text { orchid }\end{array}$ & Scrotal & & & & \\
\hline ULG + vehicle & 5 & $\begin{array}{l}1266 \cdot 7 \\
\pm 72 \cdot 6\end{array}$ & $\begin{array}{l}1260 \cdot 0 \\
\pm 49 \cdot 3\end{array}$ & $\begin{array}{r}150 \cdot 0 \\
\pm 11 \cdot 4\end{array}$ & $\begin{array}{r}135 \cdot 0 \\
\pm 21.9\end{array}$ & $\begin{array}{r}525 \cdot 0 \\
\pm 27.4\end{array}$ & $\begin{array}{r}43 \cdot 2 \\
\pm 2 \cdot 1\end{array}$ \\
\hline $\mathrm{ULG}+\mathrm{GdCl}_{2}$ & 5 & $\begin{array}{c}830.0 \\
\pm 53.8 *\end{array}$ & $\begin{array}{r}1142 \cdot 0 \\
\pm 56 \cdot 2\end{array}$ & $\begin{array}{l}132 \cdot 0 \\
\pm 8 \cdot 6\end{array}$ & $\begin{array}{r}130.0 \\
\pm 19.0\end{array}$ & $\begin{array}{r}568 \cdot 0 \\
\pm 50 \cdot 4\end{array}$ & $\begin{array}{l}59 \cdot 3 \\
\pm 4 \cdot 0 \dagger\end{array}$ \\
\hline ULG + reserpine & 5 & $\begin{array}{l}1160 \cdot 0 \\
\pm 33 \cdot 0\end{array}$ & $\begin{array}{l}1142 \cdot 0 \\
\pm 37 \cdot 3\end{array}$ & $\begin{array}{l}149 \cdot 0 \\
\pm 5 \cdot 3\end{array}$ & $\begin{array}{r}143 \cdot 0 \\
\pm 11 \cdot 4\end{array}$ & $\begin{array}{r}492 \cdot 0 \\
\pm 30 \cdot 5\end{array}$ & - \\
\hline $\mathrm{ULC}+$ reserpine $+\mathbf{C d C l}_{2}$ & 10 & $\begin{array}{r}1117 \cdot 0 \\
\pm 9 \cdot 1\end{array}$ & $\begin{array}{l}1111 \cdot 0 \\
\pm 7 \cdot 14\end{array}$ & $\begin{array}{r}142 \cdot 0 \\
\pm 11 \cdot 6\end{array}$ & $\begin{array}{r}138 \cdot 6 \\
\pm 38 \cdot 8\end{array}$ & $\begin{array}{r}502 \cdot 0 \\
\pm 38 \cdot 4\end{array}$ & - \\
\hline ULG+adrenalectomy & 5 & $\begin{array}{l}1171 \cdot 0 \\
\pm 28 \cdot 2\end{array}$ & $\begin{array}{l}1155.0 \\
\pm 13.7\end{array}$ & $\begin{array}{r}126 \cdot 2 \\
\pm 10 \cdot 3\end{array}$ & $\begin{array}{l}130 \cdot 0 \\
\pm 5 \cdot 3\end{array}$ & $\begin{array}{r}469 \cdot 0 \\
\pm 15 \cdot 0\end{array}$ & - \\
\hline $\begin{array}{l}\text { ULC +adrenalectomy }+ \\
\text { CdGl }_{2}\end{array}$ & 10 & $\begin{array}{l}1123 \cdot 0 \\
\pm 32 \cdot 2\end{array}$ & $\begin{array}{l}1141 \cdot 0 \\
\pm 82 \cdot 0\end{array}$ & $\begin{array}{r}132 \cdot 0 \\
\pm 7 \cdot 2\end{array}$ & $\begin{array}{l}130 \cdot 0 \\
\pm 6 \cdot 5\end{array}$ & $\begin{array}{r}521 \cdot 0 \\
\pm 45 \cdot 2\end{array}$ & - \\
\hline
\end{tabular}

The results are expressed in terms of the mean weight in $\mathrm{mg} \pm$ S.E. $\mathrm{ULC}=$ unilateral cryptorchidism.

* Highly significant value compared to that of the contralateral control.

$\uparrow$ Highly significant value compared to that of the ULC control.

Treatment with reserpine apparently blocked the differential effects of cadmium on the cryptorchid and scrotal testes. No significant difference between the ULC and contralateral intact testes in weight $(1117 \pm 9 \cdot 1$ versus $1111 \pm 7 \cdot 14 \mathrm{mg}$ ) and histology was detectable. Histologically, both the testes appeared almost identical to the untreated ULC control. The characteristic appearance of the ULC testis of the rats receiving cadmium was not found in those rats which were primed with reserpine and then treated with cadmium.

These observations raise the question of which of the many pharmacological properties of reserpine are relevant to the prevention of the early damaging effect of cadmium in the cryptorchid testis compared to its scrotal counterpart. In addition to its well-known depleting effect on catecholamines, reserpine also blocks their synthesis (Weiner, 1970), a process which is known to be involved in the development of testicular lesions in several mammalian species (Eguchi, 1929; VanDemark \& Baker, 1953; VanDemark \& Boyd, 1956; Boccabella, Salgado \& Alger, 1962; Chatterjee \& Paul, 1968). Evidence was sought, therefore, for the possible mediation of cadmium action through an increased release of adrenal catecholamine by subjecting animals to bilateral 
adrenalectomy through a dorsolateral incision under light ether anaesthesia, followed by induction of unilateral cryptorchidism. The rats were provided with $0.9 \% \mathrm{NaCl}$ solution as drinking water and received $200 \mu \mathrm{g}$ cortisone/day/rat throughout the experimental period. The rats were allocated to two groups, one group of rats receiving an injection of cadmium $(0.45 \mathrm{mg} / 100 \mathrm{~g}) 24 \mathrm{hr}$ after adrenalectomy, the other receiving the vehicle only. The animals were killed $72 \mathrm{hr}$ after the cadmium or vehicle treatment.

Adrenalectomy in the untreated ULC rats did not result in any kind of deviation in the appearance of the testes and accessory sex organs from those of the untreated ULC controls (Table 1). Cadmium injection in the bilaterally adrenalectomized rat apparently failed to induce any sort of adverse effect in either of the testes, irrespective of their position, within the experimental period of $72 \mathrm{hr}$. When the observation period was extended to $120 \mathrm{hr}$, it was observed that in a few test animals, both the reserpine and adrenalectomy did successfully block the differential adverse effect of cadmium between the scrotal and cryptorchid testes.

It is evident from the present experiments that the detrimental effect of cadmium and its differential influence on the scrotal and contralateral cryptorchid testes after $72 \mathrm{hr}$ could apparently be prevented by reserpine or adrenalectomy before the administration of the metal ion.

It has been reported that cadmium induces growth of the adrenal glands shortly after its administration (Paŕźzek, 1957). Adrenal medullary activity is stimulated chiefly by noxious agents and it is known that catecholamine promotes the release of adenohypophysial ACTH which, in turn, stimulates the growth of the adrenal glands (Turner, 1966). An increase in adrenal weight in the cadmium chloride-treated ULC rats compared to the untreated controls has also been recorded in the present experiments. The adrenal weight of the reserpine-treated experimental rats is not presented in the data because prior treatment with reserpine causes hypertrophy and hyperplasia of the adrenal glands (Chatterjee, 1965). As with serotonin, repeated administration of monoamine to the rat results in damage to the seminiferous epithelium. The damage is secondary to ischaemia induced by the vasoconstrictive action of serotonin (Boccabella et al., 1962). Chatterjee \& Paul (1968) reported histological damage to the seminiferous tubules of rats following treatment with epinephrine and the accessory sex organs were also adversely affected (Chatterjee, 1968; Perry, 1941). Reduced libido, and degenerative changes in the seminiferous tubules has also been reported in epinephrine-treated rabbits (VanDemark \& Boyd, 1956) and guinea-pigs (Eguchi, 1929) whilst adverse effects have been recorded on semen volume and sperm concentration in bulls (VanDemark \& Baker, 1953).

From our experimental data, it is tempting to suggest that cadmium is injurious to the vascular endothelium only when an appropriate amount of catecholamine is available. Thus, the administration of reserpine or bilateral adrenalectomy blocked the cadmium-induced haemorrhagic necrosis of the testis. Gunn \& Gould (1970), however, suggested that a metabolic system may be involved associated with permeability or other specialized function which is unique to the type of vasculature of the testis. 
The authors gratefully acknowledge the encouraging cooperation of Professor K. C. Gupta by providing the necessary laboratory facilities. Reserpine (Serpasil ${ }^{\oplus}$ ) used in this study has kindly been donated by Ciba of India, Bombay. The research work was supported by grants from the University Grants Commission to P.R. and the Indian Council of Medical Research to A.C.

\section{REFERENGES}

Boccabella, A. V., Salgado, E. D. \& Alger, E. A. (1962) Testicular function and histology following serotonin administration. Endocrinology, 71, 827.

Chatterjee, A. (1965) Effect of reserpine on adrenal activity in rats. Endokrinologie, 48, 265.

ChatTerJeE, A. (1968) Blockade of epinephrine-induced gonadal inhibition in rats by ascorbic acid. Endokrinologie, 53, 242.

Chatterjee, A. \& Paut, B. S. (1968) Testicular atrophy in rats following epinephrine administration. Endokrinologie, 52, 4.

Chatterjee, A. \& Ray, P. (1972) An early differential effect of cadmium on the scrotal and contralateral cryptorchid testes in the rat. $\mathcal{F}$. Reprod. Fert. 30, 297.

DAvis, J. R. (1965) Comparison of testicular protein labelling in cryptorchidism induced in prepuberal and adult rats. F. Reprod. Fert. 10, 149.

EGUCHI, K. (1929) Uber die pathologischen Veranderungen des Hodens bei der Adrenalinvergiftung. Jap. F. exp. Med. 11, 1129.

Glover, T. D. (1965) Changes in blood flow in the testis and epididymis of the rat following artificial cryptorchidism. Acta endocr., Copenh. Suppl. 100, 38.

Gunn, S. A. \& Gourd, T. C. (1970) Cadmium and other mineral elements. In: The Testis, Vol. 3, p. 337. Eds. A. D. Johnson, W. R. Gomes and N. L. VanDemark. Academic Press, New York.

Gunn, S. A., Gould, T. C. \& Anderson, W. A. D. (1963) The selective injurious response of testicular and epididymal blood vessels to cadmium and its prevention by zinc. Am. F. Path. 42, 685 .

Maekawa, K., Tsunenari, Y. \& Kurematsu, Y. (1966) Role of increased vascular permeability in cadmium injury of the testis. Acta anat. nippon. 41, 327.

PAŔizek, J. (1957) The destructive effect of cadmium ion on testicular tissue and its prevention by zinc. F. Endocr. 15, 56.

PERRY, J. C. (1941) Gonad response of male rats to experimental hyperadrenalism. Endocrinology, $29,592$.

Turner, C. D. (1966) General endocrinology, 4th edn. Saunders, Philadelphia.

VAnDemark, N. L. \& Baker, F. N. (1953) The effect of daily injection of epinephrine on semen production in bulls. J. Anim. Sci. 12, 956.

VANDEMARK, N. L. \& Boyd, L. J. (1956) The effect of epinephrine upon testicular function in rabbits. Int. F. Fert. 1, 245.

Weiner, N. (1970) Regulation of norepinephrine biosynthesis. A. Rev. Pharmac. 10, 273. 